\title{
Sodium dodecyl sulfate reduces bacterial contamination in goat colostrum without negative effects on immune passive transfer or the health of goat kids
}

\author{
A. Morales-delaNuez, ${ }^{*}$ I. Moreno-Indias, ${ }^{*}$ D. Sánchez-Macías, ${ }^{*}$ J. Capote,† M. C. Juste, ${ }^{*}$ N. Castro, ${ }^{*}$ \\ L. E. Hernández-Castellano, ${ }^{*}$ and A. Argüello*1 \\ *Department of Animal Science, Universidad de las Palmas de Gran Canaria, Arucas 35413, Spain \\ †Instituto Canario de Investigaciones Agrarias, La Laguna, Tenerife, Spain
}

\section{ABSTRACT}

To investigate the use of sodium dodecyl sulfate (SDS) as a biocide on goat colostrum, 2 experiments were performed. In the first, 20 goat colostrum samples were divided into 3 aliquots. A different treatment was performed on each aliquot: pasteurization $\left(56^{\circ} \mathrm{C}, 30\right.$ min) or addition of SDS to a final concentration of either 0.1 or $1 \%\left(36^{\circ} \mathrm{C}, 10 \mathrm{~min}\right)$. Immunoglobulin $\mathrm{G}$ and colony-forming units were evaluated before and after treatment. Both pasteurization and treatment with $1 \%$ SDS significantly reduced the colony-forming units in colostrum. Treatment with $0.1 \%$ SDS was not effective at reducing the colony-forming units in colostrum. The IgG concentration of pasteurized colostrum was significantly lower than that of untreated colostrum, whereas treatment with $1 \%$ SDS did not affect the colostrum IgG concentration. In the second experiment, the effects of SDS colostrum treatment on immune passive transfer were evaluated. Forty goat kids were fed either refrigerated colostrum or colostrum treated with $1 \%$ SDS twice daily for $2 \mathrm{~d}$. Blood samples were obtained at birth and every day for $5 \mathrm{~d}$. IgG, IgM, and $\operatorname{Ig} \mathrm{A}$ were measured in blood serum to monitor the passive immune transfer process. Creatinine, glucose, total cholesterol, blood urea nitrogen, bilirubin, and aspartate transaminase were also monitored to evaluate the health of kids. No differences in serum IgG, IgM, IgA, creatinine, glucose, total cholesterol, blood urea nitrogen, bilirubin, or aspartate transaminase levels were observed between groups. Our findings indicate that SDS is an efficient colostrum biocide that, unlike pasteurization, does not affect immune passive transfer or goat kid health.

Key words: biocide, colostrum, immune passive transfer, sodium dodecyl sulfate

Received June 15, 2010

Accepted August 15, 2010.

${ }^{1}$ Corresponding author: aarguello@dpat.ulpgc.es

\section{INTRODUCTION}

Artificial rearing of goat kids has been the subject of intensive research in the Animal Production Unit of Las Palmas de Gran Canaria University since 1991. To minimize or even annul the mother-kid link, which is established in the first hour after birth (Ramírez et al., 1996), kids must be removed immediately after parturition. This management practice facilitates the acceptance of artificial teats by the kid, thus improving the adoption of artificial lactation. Kids separated from their dams following birth must, however, be fed colostrum in an artificial manner. Colostrum is a nutrientrich fluid produced by female mammals immediately after giving birth. Because of its high immunoglobulin content, mainly in the form of IgG, colostrum provides antimicrobial protection and confers passive immunity, preventing diseases caused by microbial infections in the ruminant newborn (Foley and Otterby, 1978). Thus, it is generally recommended that newborns be fed with fresh high-quality colostrum as soon as possible after birth.

One means of the transmission of infectious diseases to newborns is through contaminated colostrum. Pathogens that may be transmitted via colostrum, either by direct sucking of the mammary gland or because of postharvest contamination, include bacteria such as Mycobacterium avium ssp. paratuberculosis, Salmonella spp., Listeria monocytogenes, and Escherichia coli (Steele et al., 1997), or viruses such as caprine arthritis-encephalitis (Guerrault, 1990) and bovine leukosis (Perrin and Polack, 1988). One effective method to prevent the transmission of infectious diseases to newborns is pasteurization of colostrum. Pasteurization for the destruction of pathogenic microorganisms and the reduction of endogenous milk microbiota has traditionally been carried out by heat treatment. Pasteurization plays a vital role in preventing the transmission of caprine arthritis-encephalitis. Adams et al. (1983) demonstrated the inactivation of the encephalitis arthritis virus in goat colostrum after a 60 -min pasteuri- 
zation treatment at $56^{\circ} \mathrm{C}$, whereas Moore et al. (1996) successfully inactivated the bovine immunodeficiency virus with a 30 -min pasteurization treatment at $47^{\circ} \mathrm{C}$. Further, Meylan et al. (1996) observed a reduction in the levels of Mycobacterium paratuberculosis in bovine colostrum after pasteurization $\left(62^{\circ} \mathrm{C}\right.$ for $\left.30 \mathrm{~min}\right)$.

The effects of pasteurization on cattle colostrum IgG concentration also have been studied. Both Meylan et al. (1996) and Tyler et al. (2000) found a significant reduction in IgG levels in pasteurized cattle colostrum. Reduced IgG levels diminish the transfer of passive immunity to calves (Lakritz et al., 2000). In contrast to these findings, Steinbach et al. (1981) did not observe differences in IgG bovine colostrum concentrations after pasteurization at $55^{\circ} \mathrm{C}$ for $30 \mathrm{~min}$. It is, however, well documented that immunoglobulins are thermolabile compounds, and severe heat denaturation has been observed after treatment above $75^{\circ} \mathrm{C}$ (Li-Chan et al., 1995; Chen et al., 2000). More recently, McMartin et al. (2006) heated bovine colostrum to various temperatures $\left(59,60,61,62\right.$, and $\left.63^{\circ} \mathrm{C}\right)$ and found that colostrum could be heated to $60^{\circ} \mathrm{C}$ for 120 min without changing its viscosity or IgG concentration. By contrast, heating colostrum to $63^{\circ} \mathrm{C}$ for 120 min resulted in an estimated $34 \%$ decrease in IgG concentration and a $33 \%$ increase in viscosity. Some discrepancies may arise from the finding that heating experiments performed with IgG in bovine colostrum have shown higher IgG activity retention than those with IgG in PBS buffer at a similar pH (Domínguez et al., 2001). This difference suggests a protective effect of milk components such as proteins, fats, and salts that cause a delay in denaturation and prevent aggregation of IgG during heat treatment. Although several studies investigating the thermal destruction of human and bovine immunoglobulins in colostrum and milk have been reported, little information is available on techniques for caprine colostrum decontamination that do not alter IgG content (Argüello et al., 2003).

New technologies for colostrum sanitation that are not based on heating are being developed. Recently, Trujillo et al. (2007) observed that goat colostrum could be pressure-treated (400 $\mathrm{MPa})$ to produce hygienic colostrum without affecting the IgG concentration. Hartmann et al. (2006) proposed a new approach for the prevention of mother-to-child HIV transmission in humans; they found that treating the milk of HIV1-positive mothers with relatively low concentrations of alkyl sulfate microbicides such as SDS allowed for safe breastfeeding. Alkyl sulfate microbicides disrupt virions by virtue of their surfactant (i.e., detergent) and protein-denaturing properties (Hartmann et al., 2006). Sodium dodecyl sulfate is a common ingredient in cosmetic and personal-care products (toothpastes, shampoos, bubble baths, dishwashing formulations, moisturizing lotions, baby wipes, etc.) and is used in the laboratory environment as a denaturing agent in gel electrophoresis and other protein solubilization techniques. It is readily biodegradable and is considered by the United Nations Environment Program to be "of no concern with respect to human health." The degradation of SDS and other alkyl sulfates has been described in Pseudomonas, dogs, rats, and humans (Denner et al., 1969; Thomas and White, 1989).

The aim of this work was to determine the effect of SDS treatment on caprine colostrum with respect to microbiological quality, IgG stability, and passive immune transfer in goat kids.

\section{MATERIALS AND METHODS}

\section{Sodium Dodecyl Sulfate Colostrum Treatment}

Colostrum samples $(300 \mathrm{~mL})$ were obtained at the first postpartum milking from 20 Majorera dairy goats. The mean colostrum IgG concentration was $20.56 \mathrm{mg} /$ $\mathrm{mL}$, and the mean number of colony-forming units was $6.53 \log _{10} \mathrm{cfu} / \mathrm{mL}$. Each sample was divided into 3 aliquots $(100 \mathrm{~mL}$ each). The first aliquot was pasteurized at $56^{\circ} \mathrm{C}$ for $60 \mathrm{~min}$ ( $\mathbf{P C}$ group) in accordance with the protocol described by Adams et al. (1983). The remaining 2 aliquots were treated with different concentrations of SDS. A stock solution of $10 \%(100 \mathrm{mg} /$ $\mathrm{mL}$ ) SDS (Bio-Rad Laboratories, Hercules, CA) was prepared in sterile deionized water and kept at room temperature. Colostrum $(90 \mathrm{~mL})$ was mixed with 10 or $1 \mathrm{~mL}$ of SDS stock solution, resulting in a final SDS concentration of 1 or $0.1 \%$. Colostrum was incubated with SDS for $10 \mathrm{~min}$ at $37^{\circ} \mathrm{C}$ in a water bath. The IgG and colony-forming units were measured for each of the 3 treatments.

\section{Analysis of IgG, Bacterial Counts, and Biochemical Parameters}

Quantification of $\operatorname{IgG}$, IgM, and $\operatorname{IgA}$ in colostrum or blood serum was performed using a goat ELISA kit (Bethyl Laboratories, Montgomery, TX). Quantification of colony-forming units was performed according to Beerens and Luquet (1987). Biological variables of blood serum, creatinine, glucose, total cholesterol, BUN, bilirubin, and aspartate transaminase were measured by Spotchem EZ SP-4430 (Arkray Inc., Kyoto, Japan).

\section{Immune Passive Transfer}

Prior to the experiment, a colostrum pool $(20 \mathrm{~L})$ was made from the first postpartum milking of 10 Majorera 
goats. Half of the pool $(10 \mathrm{~L})$ was refrigerated $\left(4^{\circ} \mathrm{C}\right)$ until use according to the recommendations of Argüello et al. (2003). The other $10 \mathrm{~L}$ was treated with $1 \%$ SDS in 0.5 -L containers, as described above, and refrigerated until use. The IgG concentrations and bacterial counts were measured in the original pool and in the treated colostrum. Forty Majorera goat kids, with a mean birth weight of $3.50 \mathrm{~kg}$ for males and $3.15 \mathrm{~kg}$ for females, were used in the present experiment. Immediately after birth, kids were separated from their mothers and dried. Their umbilical cords were disinfected, and they were weighed, identified, and randomly distributed into 2 groups (control or SDS treated, in reference to the type of colostrum received), each containing the same number of males and females. The 2 groups of kids were identically managed, although they were housed in separate pens. Consistent with the protocol described by Argüello et al. (2004), goat kids were bottle-fed twice daily at a rate of $100 \mathrm{~mL}$ of colostrum $/ \mathrm{kg}$ of birth BW for $2 \mathrm{~d}$. Twenty goat kids received untreated colostrum (control group), and 20 goat kids received SDS-treated colostrum (SDS group). Following the colostrum feeding period, kids were fed milk replacer (Bacilactol Cabritos, Saprogal, La Coruna, Spain; 95.5\% DM, 23.6\% CP, and $22.7 \%$ ether extract, air-dry powder basis). The animals were trained to suck from a teat connected to a unit for feeding liquid feed. Milk replacer was available twice a day (0800 and $1700 \mathrm{~h})$ for $1 \mathrm{~h}$. Samples from the jugular vein were taken every day from birth to $5 \mathrm{~d}$ postpartum to determine the biochemical profile (at birth and at d 3) and $\operatorname{IgG}, \operatorname{IgA}$, and IgM concentrations. The blood was collected in a clotting tube and centrifuged. The serum thus obtained was frozen at $-20^{\circ} \mathrm{C}$ until analysis.

\section{Statistical Analysis}

The SAS program package (Version 9.0, SAS Institute, Inc., Cary, NC) was used for statistical analyses. A PROC MIXED procedure was performed to evaluate the effect of different treatments on colostrum IgG concentrations and colony-forming units, and on serum immunoglobulins and biochemical parameter concentrations. Means were analyzed using Tukey's test (Ott and Longnecker, 2001).

\section{RESULTS AND DISCUSSION}

Table 1 shows the effects of pasteurization and SDS treatment on IgG degradation and colony-forming unit reduction. In untreated colostrum, the mean IgG concentration was $20.56 \mathrm{mg} / \mathrm{mL}$. Results agree with previous experiments in Majorera goats (Argüello et al., 2006) and are consistent with those reported by
Table 1. Immunoglobulin G concentrations and colony-forming units in untreated and treated (pasteurized or SDS-treated) goat colostrum $^{1}$

\begin{tabular}{lrrrrr}
\hline & \multicolumn{4}{c}{ Treatment } & \\
\cline { 2 - 5 } Item & Untreated & PC & SDS $_{1 \%}$ & SDS $_{0.1 \%}$ & SEM \\
\hline $\operatorname{IgG}(\mathrm{mg} / \mathrm{mL})$ & $20.56^{\mathrm{a}}$ & $14.51^{\mathrm{b}}$ & $17.97^{\mathrm{a}}$ & $18.76^{\mathrm{a}}$ & 2.34 \\
$\log _{10}(\mathrm{cfu} / \mathrm{mL})$ & $6.53^{\mathrm{a}}$ & $4.34^{\mathrm{b}}$ & $4.58^{\mathrm{b}}$ & $6.23^{\mathrm{a}}$ & 0.65 \\
\hline
\end{tabular}

${ }^{\mathrm{a}, \mathrm{b}}$ Means within a row with different superscripts are significantly different $(P<0.05)$.

${ }^{1} \mathrm{PC}=$ pasteurized colostrum $\left(56^{\circ} \mathrm{C}, 60 \mathrm{~min}\right) ; \mathrm{SDS}_{1 \%}=$ colostrum treated with a final SDS concentration of $1 \% ; \mathrm{SDS}_{0.1 \%}=$ colostrum treated with a final SDS concentration of $0.1 \%$.

Ubertalle et al. (1987) in Saanen and Camosciata goats and by Levieux et al. (2002) in Saanen and Alpine goats. The colostrum IgG concentration was reduced by $29.43,12.53$, and $8.75 \%$ in the PC, $1 \%$ SDS, and $0.1 \%$ SDS groups, respectively. Colostrum IgG degradation was significant in the $\mathrm{PC}$ samples $(P<0.05)$, whereas no statistical differences were observed with either SDS treatment. The reduction in IgG concentration following pasteurization was similar to that observed in bovine colostrum by McMartin et al. (2006) at $63^{\circ} \mathrm{C}$ for $120 \mathrm{~min}$ (34\% IgG reduction) but was lower than that reported by Argüello et al. (2003) in the same goat breed (38\%). By contrast, Steinbach et al. (1981) found no reduction in bovine colostrum IgG concentration after a heat treatment of $55^{\circ} \mathrm{C}$ for $30 \mathrm{~min}$. Trujillo et al. (2007) reported an IgG reduction that was similar to the one in the present study using high-pressure treatment.

These results provide the first data concerning the use of SDS as a sanitation agent in animal colostrum, although some information on the use of SDS to treat human colostrum is available. Hartmann et al. (2006) found that the addition of SDS to human milk did not significantly decrease the IgA concentration. In human milk treated with $1 \%$ SDS, the $\operatorname{IgA}$ concentration was $24.66 \mathrm{mg} / \mathrm{dL}$ before and $22.66 \mathrm{mg} / \mathrm{dL}$ after SDS treatment. Human colostrum is richer in IgA than IgG, but the absence of a reduction in IgA in human colostrum following SDS treatment was similar to that observed for IgG in the present study.

Bacterial contamination was strongly reduced by both the pasteurization process and 1\% SDS treatment. No differences were observed between untreated colostrum and the $0.1 \%$ SDS group. Trujillo et al. (2007) reported a similar reduction in goat colostrum colony-forming units following treatment with heat and high pressure. As in the present study, high-pressure treatments were as efficient in reducing the total bacteria population, as were heat-pasteurization treatments. These results are similar to those reported by Buffa et al. (2001), which 

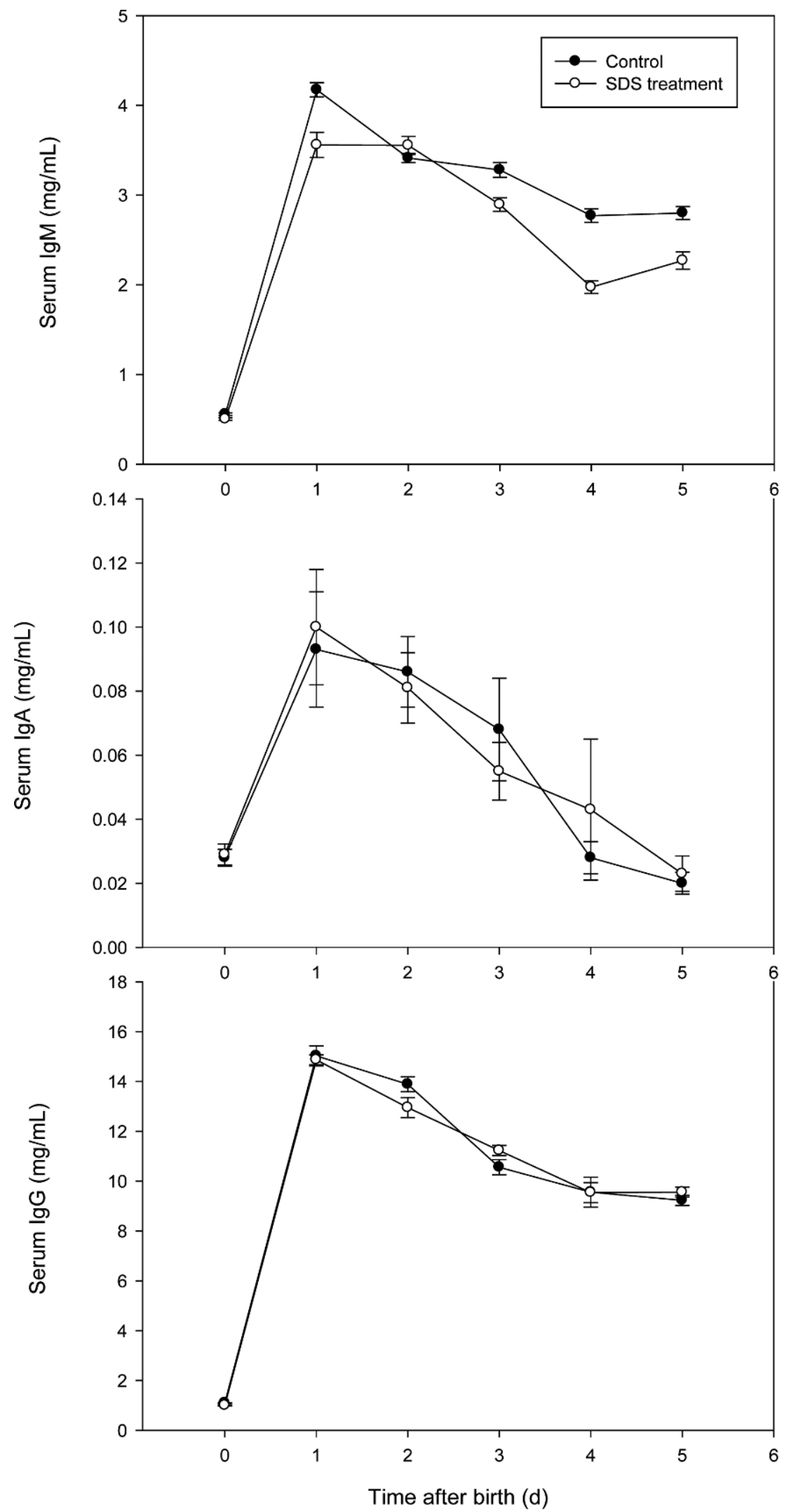

Figure 1. Immunoglobulin G, M, and A blood serum concentrations during the first $5 \mathrm{~d}$ of life in kids fed control or $1 \%$ SDS-treated colos$\operatorname{trum}(\mathrm{n}=20)$. 
Table 2. Biochemical variables in blood serum at birth and d 3 of life in kids fed control or SDS-treated colostrum

\begin{tabular}{|c|c|c|c|c|c|c|c|c|}
\hline Item & \multicolumn{2}{|c|}{ Control } & \multicolumn{2}{|c|}{ SDS treatment } & SEM & \multicolumn{3}{|c|}{$P$-value } \\
\hline Creatinine $(\mathrm{mg} / \mathrm{dL})$ & $0.56^{\mathrm{a}}$ & $0.43^{\mathrm{b}}$ & $0.58^{\mathrm{a}}$ & $0.45^{\mathrm{b}}$ & 0.03 & 0.115 & 0.003 & 0.818 \\
\hline Cholesterol (mg/dL) & 74.00 & 76.20 & 75.66 & 79.33 & 5.83 & 0.814 & 0.742 & 0.934 \\
\hline $\mathrm{BUN}(\mathrm{mg} / \mathrm{dL})$ & $9.66^{\mathrm{a}}$ & $18.66^{\mathrm{b}}$ & $10.69^{\mathrm{a}}$ & $18.60^{\mathrm{b}}$ & 1.53 & 0.343 & 0.002 & 0.267 \\
\hline Bilirubin (mg/dL) & 0.33 & 0.32 & 0.33 & 0.42 & 0.04 & 0.668 & 0.370 & 0.370 \\
\hline
\end{tabular}

${ }^{a, b}$ Means within a row with different superscripts differed significantly $(P<0.05)$.

compared the effects of pasteurization $\left(72^{\circ} \mathrm{C}, 15 \mathrm{~s}\right)$ and high pressure $\left(500 \mathrm{MPa}, 15 \mathrm{~min}, 20^{\circ} \mathrm{C}\right.$ ) on colony-forming units in goat milk. Hartmann et al. (2006) concluded that HIV-1 can be inactivated in human milk with inexpensive microbicides, while conserving important human milk constituents. We hypothesize that, similar to its effects on HIV-1, SDS treatment may also inactivate the caprine arthritis encephalitis virus, although this hypothesis requires further investigation.

Figure 1 shows the $\operatorname{IgG}$ concentration in goat kid blood serum observed during the first $5 \mathrm{~d}$ of life. No significant differences between IgG concentrations were observed between groups. Previous reports using the radial immunodiffusion technique (Argüello et al., 2004; Castro et al., 2005) suggest that goat kids are agammaglobulinemic at birth. Consistent with studies by Rodríguez et al. (2009), IgG blood serum concentrations in the present experiment were low at birth. Following birth, IgG concentrations ranged from 10.56 to $22.14 \mathrm{mg} / \mathrm{mL}$ and were affected by postpartum time. After the initial increase in IgG serum concentrations between birth and d 1, there was a slight decrease in both experimental groups. Argüello et al. (2004), Castro et al. (2007), and Rodríguez et al. (2009) reported similar blood serum peak times for IgG concentrations in Majorera kids. This temporal change in $\operatorname{IgG}$ concentration is in accordance with observations made by Logan et al. (1978) in calves, where the maximum IgG level was reached between 16 and $48 \mathrm{~h}$ postpartum. Argüello et al. (2004) described IgG concentrations of $5.19 \mathrm{mg} / \mathrm{mL}$ in kids with failure in immune passive transfer; neither group in the present experiment had IgG concentrations indicative of immune passive transfer failure. Thus, no adverse effects on passive immune transfer resulting from SDS treatment of colostrum were observed at any time.

The IgA concentrations in goat kid blood serum observed during the first $5 \mathrm{~d}$ of life are shown in Figure 1. Immunoglobulin A was $0.03 \mathrm{mg} / \mathrm{mL}$ at birth, whereas Rodríguez et al. (2009) reported that IgA was undetectable in kid serum at birth in the same breed.
After birth, IgA serum concentrations ranged from 0.07 to $0.15 \mathrm{mg} / \mathrm{mL}$ and were affected by postpartum time in a way similar to that described by Rodríguez et al. (2009). Immunoglobulin A concentrations at birth and on $\mathrm{d} 4$ and 5 were lower than those obtained on $\mathrm{d} 1$ to 3. After the initial increase in IgA serum concentrations between birth and $d$, a subsequent decrease in these concentrations occurred in both experimental groups. In calves, a similar decrease in IgA serum concentrations was observed beginning $48 \mathrm{~h}$ postpartum (Logan et al., 1973). No effects on IgA serum concentrations as a result of SDS treatment of colostrum were observed.

Goat kids had an IgM concentration of $0.53 \mathrm{mg} / \mathrm{mL}$ at birth (Figure 1). A previous study (Rodríguez et al., 2009) reported an IgM concentration of $1.49 \mathrm{mg} / \mathrm{mL}$ at birth in the same breed. The serum IgM concentrations were lower at birth than on d 1 to 5 in both experimental groups. Sodium dodecyl sulfate treatment did not affect IgM serum concentrations.

To evaluate the possible toxic activities of SDS, several biochemical variables (creatinine, glucose, total cholesterol, BUN, bilirubin, and aspartate transaminase) were evaluated at birth and on d 3 of life (Table 2). Sodium dodecyl sulfate treatment did not show significant effects on any biochemical variables. Glucose, total cholesterol, bilirubin, and aspartate transaminase were not affected by time. From birth to d 3, creatinine concentrations decreased in both groups, whereas BUN levels increased. Blood urea nitrogen concentration increase might be related to the high amount of protein present in colostrum (Argüello et al., 2006). Biochemical values are consistent with a report by Atasoglu et al. (2008) in Turkish Saanen goats.

\section{CONCLUSIONS}

Treatment of goat colostrum with 1\% SDS reduced the bacterial load to a degree similar to that seen with pasteurization. The destruction of $\operatorname{IgG}$ was, however, significantly lower in SDS-treated colostrum than in pasteurized colostrum. Furthermore, goat kids fed SDS- 
treated colostrum exhibited no pathological differences in biological parameters measured in blood serum and showed normal immune passive transfer.

\section{ACKNOWLEDGMENTS}

This work was supported by grant AGL 2006-08444/ GAN from the Spanish government.

\section{REFERENCES}

Adams, D. S., P. Klevjer-Anderson, J. L. Carlson, T. C. McGuire, and J. R. Gorham. 1983. Transmission and control of caprine arthritisencephalitis virus. Am. J. Vet. Res. 44:1670-1675.

Argüello, A., N. Castro, S. Ãlvarez, and J. Capote. 2006. Effects of the number of lactations and litter size on chemical composition and physical characteristics of goat colostrum. Small Rumin. Res. 64:53-59.

Argüello, A., N. Castro, J. Capote, R. Ginés, F. Acosta, and J. L. López. 2003. Effect of refrigeration, freezing-thawing and pasteurization on IgG goat colostrum preservation. Small Rumin. Res. 48:135-139.

Argüello, A., N. Castro, J. Capote, J. W. Tyler, and N. M. Holloway. 2004. Effect of colostrum administration practices on serum IgG in goat kids. Livest. Prod. Sci. 90:235-239.

Atasoglu, C., I. Y. Yurtman, T. Savas, M. Gültepe, and O. Özcan. 2008. Effect of weaning on behavior and serum parameters in dairy goat kids. Anim. Sci. J. 79:435-442.

Beerens, H., and F. M. Luquet. 1987. Guide Pratique d'Analyse Microbiologique des Laits et des Produits Laitiers. Lavoisier at Apria, Paris, France.

Buffa, M., B. Guamis, C. Royo, and A. J. Trujillo. 2001. Microbiological changes throughout ripening of goat cheese made from raw, pasteurized and high-pressure-treated milk. Food Microbiol. 18:45-51.

Castro, N., J. Capote, S. Ãlvarez, and A. Argüello. 2005. Effects of lyophilized colostrum and different colostrum feeding regimens on passive transfer of immunoglobulin G in Majorera goat kids. J. Dairy Sci. 88:3650-3654.

Castro, N., J. Capote, L. Morales, E. Quesada, H. Briggs, and A. Argüello. 2007. Short communication: Addition of milk replacer to colostrum whey: Effect on immunoglobulin G passive transfer in Majorera kids. J. Dairy Sci. 90:2347-2349.

Chen, C. C., Y. Y. Tu, and H. M. Chang. 2000. Thermal stability of bovine milk immunoglobulin G (IgG) and the effect of added thermal protectants on the stability. J. Food Sci. 65:188-193.

Denner, W. H., A. H. Olavesen, G. M. Powell, and K. S. Dodgson. 1969. The metabolism of potassium dodecyl $\left[{ }^{35}-\mathrm{S}\right]$ sulphate in the rat. Biochem. J. 111:43-51.

Domínguez, E., M. D. Pérez, P. Puyol, L. Sánchez, and M. Calvo. 2001. Effect of $\mathrm{pH}$ on antigen-binding activity of $\mathrm{IgG}$ from bovine colostrum upon heating. J. Dairy Res. 68:511-518.

Foley, J. A., and D. E. Otterby. 1978. Availability, storage, treatment, composition, and feeding value of surplus colostrum: A review. J. Dairy Sci. 61:1033-1060.

Guerrault, P. 1990. Apport de colostrum: Plusieurs methodes. La Chevre 180:30-31.

Hartmann, S. U., B. Wigdahl, E. B. Neely, C. M. Berlin, C. L. Schengrund, H.-M. Lin, and M. K. Howett. 2006. Biochemical analysis of human milk treated with sodium dodecyl sulfate, an alkyl sulfate microbicide that inactivates human immunodeficiency virus type 1. J. Hum Lact. 22:61-74.
Lakritz, J., J. W. Tyler, D. E. Hostetler, A. E. Marsh, D. M. Weaver, J. M. Holle, B. J. Steevens, and J. L. Denbigh. 2000. Effects of pasteurization of colostrum on subsequent serum lactoferrin concentration and neutrophil superoxide production in calves. Am. J. Vet. Res. 61:1021-1025.

Levieux, D., F. Morgan, N. Geneix, I. Masle, and F. Bouvier. 2002. Caprine immunoglobulin G, $\alpha$-lactoglobulin, $\beta$-lactalbumin and serum albumin in colostrums and milk during the early post partum period. J. Dairy Res. 69:391-399.

Li-Chan, E., A. Kummer, J. N. Losso, D. D. Kitts, and S. Nakai. 1995. Stability of bovine immunoglobulins to thermal treatment and processing. Food Res. Int. 28:9-16.

Logan, E. F., C. H. McMurray, D. G. O'Neill, P. J. McParland, and F. J. McRoy. 1978. Absorption of colostral immunoglobulins by the neonatal calf. Br. Vet. J. 134:258-262.

Logan, E. F., W. J. Penhale, and R. A. Jones. 1973. Changes in the serum immunoglobulin levels of colostrum-fed calves during the first 12 weeks postpartum. Res. Vet. Sci. 14:394-397.

McMartin, S., S. Godden, L. Metzger, J. Feirtag, R. Bey, J. Stabel, S. Goyal, J. Fetrow, S. Wells, and H. Chester-Jones. 2006. Heat treatment of bovine colostrum. I: Effects of temperature on viscosity and immunoglobulin G level. J. Dairy Sci. 89:2110-2118.

Meylan, M., D. M. Rings, W. P. Shulaw, J. J. Kowalski, B. Bech-Nielsen, and G. F. Hoffsis. 1996. Survival of Mycobacterium paratuberculosis and preservation of immunoglobulin $\mathrm{G}$ in bovine colostrum under experimental conditions simulating pasteurization. Am. J. Vet. Res. 57:1580-1585.

Moore, E. C., D. Keil, and K. Coats. 1996. Thermal inactivation of bovine immunodeficiency virus. Appl. Environ. Microbiol. 62:42804283.

Ott, R. L., and M. Longnecker. 2001. An Introduction to Statistical Methods and Data Analysis. 5th ed. Duxbury Press, Pacific Grove, $\mathrm{CA}$

Perrin, G., and B. Polack. 1988. Bovine colostrum warning. Vet. Rec. 122:240.

Ramírez, A., A. Quiles, M. L. Hevia, F. Sotillo, and M. C. Ramírez. 1996. Influence of forced contact on the maternal-filial bond in the domestic goat after different periods of postpartum separation. Small Rumin. Res. 23:75-81.

Rodríguez, C., N. Castro, J. Capote, A. Morales-Delanuez, I. MorenoIndias, D. Sánchez-Macías, and A. Argüello. 2009. Effect of colostrum immunoglobulin concentration on immunity in Majorera goat kids. J. Dairy Sci. 92:1696-1701.

Steele, M. L., W. B. McNab, C. Poppe, M. W. Griffiths, S. Chen, S. A. Degrandis, L. C. Fruhner, C. A. Larkin, J. A. Lynch, and J. A. Odumeru. 1997. Survey of Ontario bulk tank raw milk for foodborne pathogens. J. Food Prot. 60:1341-1346.

Steinbach, G., B. Kreutzer, and H. Meyer. 1981. Zum einfluss der erwarmung auf den immunbiologischen wert des rinderkolostrums. Monatsh. Veterinarmed. 36:29-31.

Thomas, O. R., and G. F. White. 1989. Metabolic pathway for the biodegradation of sodium dodecyl sulfate by Pseudomonas sp. C12B. Biotechnol. Appl. Biochem. 11:318-327.

Trujillo, A. J., N. Castro, J. M. Quevedo, A. Argüello, J. Capote, and B. Guamis. 2007. Effect of heat and high-pressure treatments on microbiological quality and immunoglobulin G stability of caprine colostrum. J. Dairy Sci. 90:833-839.

Tyler, J. W., J. Lakritz, D. E. Hostetler, V. Douglas, D. M. Waver, B. J. Steevens, J. Holle, and J. Denbigh. 2000. Effect of pasteurization at 76 and $63^{\circ} \mathrm{C}$ on the absorption of colostral IgG in calves. J. Dairy Res. 67:619-623.

Ubertalle, A., G. Ladetto, E. Cauvin, and P. Mazzocco. 1987. Colostro caprino: Caratteristiche del latte ottenuto nelle prime 24 ore post partum. Summa 4:239-242. 